\title{
TOURISM TO SOCIO CULTURE AND ECONOMY OF COMMUNITY IN PANUSUPAN PURBALINGGA
}

\author{
Agung Edi Rustanto \\ agung@plj.ac.id \\ Donny Oktavian Syah \\ Business Administration Program, Politeknik LP3I Jakarta \\ Gedung Sentra Kramat, Jl. Kramat Raya No. 7/9 Jakarta 10450, Indonesia
}

received: 08/09/17; revised: 14/12/17; published: 27/06/18

\begin{abstract}
The aim of this research is to study the impact of tourism development to socio-culture and economy of community in Panusupan village, Rembang, Purbalingga. The research, which was conducted in the end of 2016, uses descriptive quantitative method. Sampling technique used is random sampling technique. Survey was conducted to 100 respondents. The data are analyzied by using simple linear regression The result of this research shows that partially tourism development gives impact $31.5 \%$ to socio culture, $45.6 \%$ to socio economy whereas the impact of socio culture to socio economy is $32.0 \%$.
\end{abstract}

Keywords: tourism; socio-cultural implication; economic implication; panusupan-purbalingga

\section{INTRODUCTION}

Sometimes, travellers (tourists) visiting to an unknown area make it popular and grow. Moreover the booming of social media contributes its development. They promote the uniqeness of an area on social media by uploading not only photos but also review of the scene. Including some tourist attractions in Purbalingga, central Java. The visitors to those places were increasing after they saw them on social media.

The increasing number of new tourist attractions indicated that Purbalingga district gave enough attention and support to the tourist development. At the beginning, Purbalingga's Owabong waterboom became populair tourism icon in social media. Now, more various and exciting tourist attractions have been built and promoted via social media.

Then more districts in Purbalingga promoted their tourist attractions. One of them was Rembang distric especially Panusupan village. At the beginning the people of Panusupan didn't support the idea of developing tourism in the area. Then the local government gave them some training on tourism, such as guiding visitors, managing homestay, promotion etc. Having trained, they could serve visitors well.

Villages also competed each other to create different attractions. From January to September 2016 the number of visitors to Panusupan reached 98,000 people. Panusupan built some new tourist attractions and enhanced the old ones. Some of them are Puncak
Senderan, Puncak Batur, sungai Watu Mujur, Igir Wringin, green park Batu Gilang, jembatan cinta, Puncak Srimbar Jaya and Ardi Lawet.

The growth of tourism and the increasing travelers affect the local people both positively and negatively. As Gee (1989) says in his book The Travel Industry that "as tourism grows and travellers increases, so does the potential for both positive and negative impacts". Positive impacts occur when tourist providers make regulations that are able to localize bad impacts from visitors to local people. From socio cultural point of view, people become more open minded, more tolerate and they tend to preserve local culture. People can improve their communication skill and interaction more broadly. However, negligible negative impacts are quite influential for the local community. They may change in terms of speaking, dressing, behaving and life style that is considered less polite. The tourism providers should improve the regulations to minimize bad impacts.

Ismayanti (2009) says that attraction is the main element to elevate a tourist destination. It means that the more attractive a place is, the more visitors to come.

Tourism has several purposes, (a) to gain benefits : nation income, economy growth, (b) to eliminate poverty by opening employment and tackling unemployment, (c) to provide leisure places for society, as well as to the image of the nation and strengthen the nation's identity, foster a sense of homeland through the exploitation of domestic attraction, (d) to preserve nature, environment and resources, while promoting culture through tourism 
marketing, (e) to strengthen friendship among nations by understanding the value of religion, customs and community life.

According to Spillane (2002) there are five essential elements that tourist attraction must have, namely: (1) attraction (2) facilities (3) infrastructure (4) transportation (5) Hospitality. Panusupan village has those five requirements. The villagers created unique tourism exploring the natural beauty of their village. They built tree houses with beautiful scenery surrounding and brigde of love which is made from natural material like bamboo and wood. Visitors are attracted to take photos there. The facilities available are made not only for comfort but also safety. In this research, five essential elements from Spillane become $\mathrm{X}$ Variable (exogenous variable).

Panusupan village also began to renovate the infrastructures. Road access to tourist destinations were widen and fixed. Road signs were also installed in crossroad to provide information for visitors heading to a certain place. Unfortunately transportation has not been available to take visitors. But they can rent villagers's cars to take them. And also rent motorcycle or ojek. Hospitality is part of Panusupan life. Whoever coming to their village are welcome.

Social change should be anticipated due to tourism development. Himes and Moore (in Nanang Martono, 2001) state that social change has three dimensions : structural, cultural, and interactional. Structural dimension refers to social structure in society, including role change, new role in society, social strata, and social institution. Cultural dimension refers to cultural changes in society, including innovation, diffusion, and integration. Interactional dimension refers to social interaction changes in society.

Koentjaraningrat (2009) says that there are seven elements of culture that may change due to tourism. (1) Language, native language may have different accent, pronunciation, and also vocabularies. Interaction with travellers from other area make the native language influenced; 2) Knowledge, panusupan people are mostly farmers. The way of thinking and new technology were introduced by travellers; (3) Social organization, pokdarwis or kelompok sadar wisata was then established in Panusupan; (4) Technology and equipment, the use of new technology such as internet and smartphone was also introduced. (5) Livehood system and economy system, agriculture was the major employment in Panusupan. When tourism grew, people started to run other business such as restaurant, homestay, and transportation. (6) Religious system, ardi lawet was one of tourist attractions in Panusupan. People went there to pray on certain intention. But then people went there only for leisure. (7) Art, travellers usually require traditional performing art so that the tradition is well-preserved.

Those seven dimension intoduced by Koentjaraningrat become indogen variable (Y).
Suratmo (2004) says impact is changes in environment due to human activities. The socioeconomic impacts of a development, especially in developing countries, are showed in the following components which are defined as socio-economic indicators of the community: (1) generation of jobs, (2) the development of economic structure, that is the rising of economy activities such as transportation, restaurant, food stall, store, etc, (3) increasing income, (4) public health, (5) community perception, (6) population growth

In this research, those six indicators becomes endogenous variables (Y2).

\section{METHOD}

This research uses descriptive quantitative method. To test the impacts among variables, verification method is used. There are two variables in this research: independent and dependent variables. Description analysis is used to describe each variable. Verification analysis is used to test the research hypothesis explaining whether the variables influence each other.

The population in this research are 556 villagers living in Panusupan, Purbalingga. The observasion was conducted in 2017. The sampling technique is random sampling. Based on Slavin formula (Iskandar, 2009), with the margin of error $10 \%$, the minimal samples are 85. In this research, 100 respondents are the samples.

The research instrument is developed based on various theories about the variables in this study. Table 1 is the operationalization of variables used to develop research instruments. Instruments were developed using the interval scale approach (differential semantic).

Data collection was conducted with three approaches: observation, interview, and questioner. The data source used are combining both primary data and secondary data. The primary data were collected through interview and giving questionairre to the samples. While the secondary data were any records dealing with research objects.

The data analysis technique used to test the hypothesis is simple linear regression. This method is used to study relationships between two variables: dependent and independent. Its purpose is to study the impact of independent variable (exogen) towards dependent variable (endogenous) as shown in figure 1.

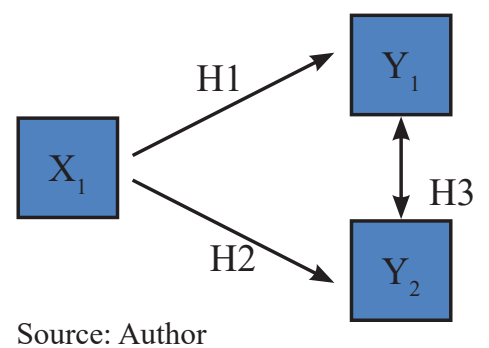

Figure 1. Conceptual Framework 
Multiple linear regression is used to study the impact of two or more independent variables towards dependent variable.

Hypothesis: (1) There is positive and significant impact of tourism development to socio-culture in Panusupan village; (2) There is positive and significant impact of tourism development to economy in Panusupan village; (3) There is positive and significant impact of socio cultural development to economy development in Panusupan village.

\section{RESULTS}

The followings are the testing results of the impacts of tourism development on socio-cultural and economic variables by using SPSS based on the paradigm of structural equation model of the following mathematical models:

Structural 1: $\mathrm{Y}_{1}=\mathrm{a}+\mathrm{bX}$

Structural 2: $Y_{2}=a+b X$

Structural $3: \mathrm{Y}_{2}=\mathrm{a}+\mathrm{bY}_{1}$

Table 1. Research Variable Operation

\begin{tabular}{|c|c|c|}
\hline Variable & Dimension & Indicator \\
\hline \multirow{10}{*}{$\begin{array}{l}\text { Tourism } \\
\text { (X) }\end{array}$} & Attraction & Increasing tourism variety \\
\hline & & $\begin{array}{l}\text { Providing the best tourism } \\
\text { potential }\end{array}$ \\
\hline & Facilities & Photography \\
\hline & & $\begin{array}{l}\text { Providing Food and Beverage } \\
\text { needs }\end{array}$ \\
\hline & Infrastructure & Tourism object development \\
\hline & Transportation & Road access improvement \\
\hline & & Transportation infrastructure \\
\hline & Hospitality & improvement \\
\hline & & Manner \\
\hline & & Communication Strategy \\
\hline \multirow{12}{*}{$\begin{array}{l}\text { S o c i o - } \\
\text { cultural } \\
\text { (Y1) }\end{array}$} & Language & $\begin{array}{l}\text { Local Language } \\
\text { Foreign Language }\end{array}$ \\
\hline & Social organization & Tourism Organization \\
\hline & knowledge system & Development \\
\hline & System of life & Tourism knowledge \\
\hline & equipment and & Use of gadget \\
\hline & technology & Internet based knowledge \\
\hline & System of livelihood & Transportation services \\
\hline & & Accommodation services \\
\hline & Religious System & Food and Beverage Products \\
\hline & Art & Religious Tolerance \\
\hline & & Local Arts \\
\hline & & Foreign Arts \\
\hline \multirow{6}{*}{$\begin{array}{l}\text { Economic } \\
(\mathrm{Y} 2)\end{array}$} & Employment & Unemployment reduction \\
\hline & The development of & Increasing number of shops \\
\hline & economic structure & Increasing transportation \\
\hline & Increasing income & activities \\
\hline & of the community & Increasing amount of income \\
\hline & Public health & $\begin{array}{l}\text { Increasing number of income } \\
\text { sources }\end{array}$ \\
\hline
\end{tabular}

\begin{tabular}{ll}
\hline C o m m u n i y & Awareness toward diseases \\
perception & Increasing awareness on \\
I n c r e a s i n g & sanitation \\
Population & $\begin{array}{l}\text { Perception of tourism } \\
\text { potential utilization }\end{array}$ \\
& $\begin{array}{l}\text { Perception of employment } \\
\text { development } \\
\text { Increasing living interest } \\
\text { of the community from } \\
\text { surrounding area }\end{array}$ \\
\hline
\end{tabular}

Source: Adopted from Spillane (2002); Koentjaraningrat (2009); Suratmo (2004).

The structural equation 1 is $\mathrm{Y} 1=55.767+0.130 \mathrm{X} 1$. Dependent Variable is socio-cultural development and Independent Variable is tourism development. Based on the regression model, it can be seen that the constant of 55.767 means that if the variable of tourism development is zero; the social culture development is equal to 55,767 units. The value of regression coefficient variable of tourism development is 0.130 which means that for each unit of increase on the tourism development, there is an increase of 0.130 .

Based on the results of data analysis, there is a positive and significant impact of tourism development on the socio-cultural development of the local communities. From the analysis result, it is found that the R2 coefficient value of tourism development is equal to 0,315 , by taking significant level of $\alpha$ equals to $5 \%$, the $t$ value of 2,202 is obtained, hence the $t$ value of the table equals to 1,660 , thus illustrating that the contribution of variable $X$ (tourism development) in Panusupan Village to variable Y1 (socio-cultural development) equals $31.5 \%$. The structural equation 2 is $\mathrm{Y} 2=41.305+0.159 \mathrm{X} 1$. Dependent Variable is socio-cultural development and Independent Variable is tourism development.

Based on the regression model, it is found that the constant is 41.305, which indicates that if the variable of tourism development is zero, then the socio-cultural development is 41.305 units. The value of regression coefficient variable of tourism development equals 0.159 which means that for each unit of increase of tourism development, there is an increase of 0.159 . The results of data analysis also illustrate the effects of tourism development on social-economic development of the local communities.

The coefficient value of $\mathrm{R} 2 \mathrm{X}$ (tourism development) to social economy is 0.456 . While from the test results, the $t$ count value of 2.136 is obtained by taking a significant level of $\alpha$ of $5 \%$, hence the t value of the table amounted to 1.660 , thus the calculated t count value $>t$ table or $2.136>1.660$, so $\mathrm{H} 0$ is rejected or in other words tourism development has a positive and significant impact of $45.6 \%$ on social economy.

The structural equation 3 is Y2 $=44.220+0.098 \mathrm{Y} 1$. Dependent Variable is socio-cultural development and 
Independent Variable is tourism development. Based on the regression model, it can be found that the constant is 44.220; which states that if the variable of tourism development is zero, the socio-cultural development is 44.220 units. The regression coefficient value of tourism development variable is 0.098 which means that for each increase of tourism development, there is an increase of 0.098 . The results of data analysis illustrate and show the impact of Y1 (social culture) on Y2 (social economy) with R2 coefficient value of 0,320 which then obtains $t$ value count of 2,410 and by taking significant level of $\alpha$ equals to $5 \%$, hence $\mathrm{t}$ value table is equal to 1,660 , so $\mathrm{t}$ count $>\mathrm{t}$ table or $2.410>1660$, thus H0 is rejected or in other words, social-cultural development affects the socio-economic development by $32.0 \%$.

The overall results of the analysis through regression can be illustrated by the model in Table 2 .

Table 2.

\begin{tabular}{lr}
\hline \multicolumn{1}{c}{ Causality } & Impact $\left(\mathrm{R}^{2}\right.$ Value $)$ \\
\hline $\begin{array}{l}\text { The impact of tourism development on } \\
\text { socio-cultural development }\end{array}$ & 0.315 \\
$\begin{array}{l}\text { The impact of tourism development on } \\
\text { social economic development }\end{array}$ & 0.456 \\
The impact of socio-cultural development \\
on social economic development
\end{tabular}

\section{DISCUSSION}

The results of descriptive analysis show that tourism development has positive and significant impacts to sociocultural and social-economic development. Panusupan Village is originally known for one of its tourist locations of religious tourism called Ardi Lawet. The visitors come with the intention of praying. The access road to reach this tourist location is very exhausting because visitors have to climb high hills. The high hills have splendid landscapes, so the Panusupan villagers develop these spots into new tourist locations in the hills, rivers, rice fields and waterfalls with beautiful scenic attractions as a great place to take pictures or selfie.

The development of tourist locations in terms of quantity and quality generally has a role in the sociocultural and economic changes of the local community who live not far from the tourist sites. This is in line with previous research in other locations (Mbaiwa, 2008). Tourism development becomes an attraction for tourists coming from various regions. Some of the local tourists come from places close to the tourist sites; villagers from places which are still in the sub-district of Rembang and other sub-district residents who come from Purbalingga Regency. Some tourists also come from farther areas either from places that are still in Central Java province or from outside of Central Java Province.
The impact of tourist visits increases the diversity of language dialects with distinct differences from other villages, districts and provinces. Road access to Panusupan Village is growing and facilitating transportation and community distribution activities in conducting economic activities. Tourists' habit of using technological advances has become a new custom which is slowly imitated by the local communities.

The calculation results show that the effect of tourism development on socio-cultural development is 0.315 or $31.5 \%$. This positive value indicates that with better development of tourism in Panusupan Village, the social and cultural conditions of the community in Panusupan Village are also getting better.

The increasing number of tourists in Panusupan Village has implications for the increasing quantity and quality of Panusupan villagers' interaction with tourists (domestic) visiting the village. An example of the implication is the villagers are more familiar with the use of technology and the use of social media used by the visiting tourists.

The results are in line with Bakr M. Aly Ahmed's research (2015) which studied coastal tourism in Egypt and in the United States, stating that coastal tourism growth significantly affects the local economy, economy, environment and culture. Tourism that grows in Panusupan Village increases the attraction for visitors. The large number of visitors with diverse socio-cultural backgrounds affects the socio-cultural changes of the local community. In the results of this study, the development of tourism has a positive and significant impact on the socio-cultural development of the community in Panusupan Village. The results of this study are also supported by the results of Manika Singla's research (2014) in the city of Jaipur, India, which states that the people of Jaipur are aware of the impacts of the tourism development both in positive and negative terms. The majority of the community reiterated that they are optimistic that tourism and tourism development will affect both the social and cultural life of the community.

The calculation shows that the effect of tourism development on social economy is 0.456 or $45.6 \%$. This positive value indicates that with better tourism development in Panusupan Village, the social-economic conditions of the community in Panusupan Village are getting better. An example of the positive impact of tourism development is the growing economic condition of the people through the sale of food and beverages that they provide to be sold to the visiting tourists. Some residents' houses also become home-stays for tourists who wish to stay.

The results of these calculations are in line with the research of Lincoln (2013) in Bangladesh; Zadel and Bogdan (2013) in Croatia which conclude that the tourism business is very important for the economy because it has direct impacts on employment, the 
balance of payments and the community in terms of educational and cultural benefits. Even in macro aspect, there is a fairly strong relationship between tourism revenue and economic growth, as implied by the results of a study in Greece (Nikolaos, 2004). Even the growth of tourism can bring rapid positive economic growth impacts such as the case in Trentino-Alto Adige, northern Italy (Brida et al, 2010).

With the development of tourism in Panusupan Village, opportunities for infrastructure improvement and income generation for the community are also growing. Road access in the Village is getting better and the number of sellers and shops that take advantage of the opportunities from the large number of potential buyers visiting tourist sites is also growing. Income from visitors also affects the increasing standard of living of the local communities. This is supported by research results from Zadel and Bogdan (2013) which states that the Republic of Croatia is a tourismoriented country that also "lives" from tourism which is marked by particular seasons during the summer months. Tours can be enjoyed throughout the year, thus tourism and cultural development will increase the economic development.

The calculation results show the socio-cultural development impact on social economic that is equal to 0.320 or $32.0 \%$. This positive value indicates that with better socio-cultural development in Panusupan Village, the socio-economic development of the community in Panusupan Village is also getting better.

The results are in line with the research of Vishwanatha and Chandrashekara (2014) which states that the socio-cultural development due to tourism has a positive and significant impact which strongly improves the local economy through the benefits of tourism. Tourism will encourage local food security and local livelihoods as its significant positive impact which will then contribute to the development of other infrastructure and social systems, such as public services like health conditions, child education and access to safe drinking water. Tourism also serves as the motor of conservation and poverty reduction.

\section{CONCLUSION}

According to the discussion, it can be concluded that the development of tourism in Panusupan Village in terms of quality and quantity brings positive and significant impacts on the socio-cultural development of the society. Tourism development also has positive and significant impacts on the economic development of the community. Socio-cultural development has a positive and significant impact on the economy of Panusupan Village community. The developments of tourism in Panusupan Village are the improvement of services and infrastructures of the old tourist location and the making of new tourist locations that suit the needs of tourists in the present era in the form of beautiful locations and which are very good for taking picture and selfie (personal portrait).

Based on the calculation of the data processing, tourism development partially affects the socio-cultural development by $31.5 \%$. Tourism development can be an attraction for tourists with diverse cultural background that can bring impacts on the socio-cultural conditions of the local communities. Based on the calculation of data processing, the tourism development partially affects the socio-economic development by $45.6 \%$. The increasing number of tourists will help improve the economic conditions of the local community. Based on the calculation of data processing, socio-cultural development affects the social economy by $32.0 \%$. Improved socio-cultural condition will also empower the community in terms of knowledge, insight, and social interaction that also lead to the improvement of the local community's economy.

\section{REFERENCES}

Bakr M. Aly Ahmed. 2015. Social and Cultural Impacts of Tourism Growth in Coastal Environments and the Potential for Sustainability: Case Study of Egypt and USA. International Journal of Arts and Humanities. 1(2): 32-48.

Brida, J.G, Barquet, A., dan Risso, W.A. 2010. Causality Between Economic Growth and Tourism Expansion. Tourismos. 5(2): 87-98.

Gee, Chuky.Y. 1989. The Travel Industry. New York: Van Nostrand Reinhold

Iskandar. 2009. Metodologi Penelitian Pendidikan dan Sosial, Modern. Jakarta: Persada Pers.

Ismayanti. 2009. Pengantar Pariwisata. Jakarta: Grasindo. Koentjaraningrat. 2009. Pengantar Ilmu Antropologi. Jakarta: Rineka Cipta.

Lincoln, Z. 2013. Socio-Economic and Cultural Impacts of Tourism in Bangladesh. European Scientific Journal. 10(2): 326-331.

Manika, S. 2014. A Case Study on Socio-cultural Impacts of Tourism in the City of Jaipur, Rajasthan: India. Journal of Business Management \& Social Sciences Research. 3(2): 10-23.

Martono, N. 2011. Sosiologi Perubahan Sosial Perspektif Klasik, Modern, Postmodern, dan Poskolonial. Jakarta: Rajawali Pers.

Mbaiwa, J.E. 2005. Socio-Economic and Cultural Impacts of Tourism Development in the Okavango Delta, Botswana. Journal of Tourism and Cultural Change. 2(3): 163-185.

Nikolaos, D. 2004. Tourism as a Long-Run Economic Growth Factor: An Empirical Investigation for Greece Using Causality Analysis. Tourism Economics. 10(3): 305-316. 
Spillane, J.J. 2002. Ekonomi Pariwisata Sejarah dan Prospeknya. Yogyakarta: Kanisius.

Suratmo, F.G. 2004. Analisis Mengenai Dampak Lingkungan. Yogyakarta: Gadjah Mada University Press.

Vishwanatha, S. dan Chandrashekara, B. 2014. An
Analysis of Socio-Cultural Impacts of Ecotourism in Kodagu District. American Journal of Research Communication. 2(7): 135-147.

Zadel, Z. dan Bogdan, S. 2013. Economic Impact of Cultural Tourism. UTMS Journal of Economics. 4(3): 355-366. 